\title{
OBSERVATIONS ON THE BLOOD IODINE. I. THE BLOOD IODINE IN HEALTH, IN THYROID AND CARDIORENAL DISEASE, AND IN LEUKEMIA
}

\author{
By KENNETH B. TURNER, ARLENE DeLAMATER AND WILLIAM D. PROVINCE \\ (From the Department of Medicine, College of Physicians and Surgeons, Columbia University, \\ and the Presbyterian Hospital, New York City)
}

(Received for publication February 7, 1940)

The total amount of iodine in the circulating blood of a normal human adult usually does not exceed half a milligram. It can be understood, therefore, why early investigators doubted that iodine was a constant component of the blood. It was not until 1923 that a method (1) was introduced that was sufficiently delicate to permit a quantitative study of the blood iodine. Since that time, numerous procedures have been brought forward. These have often differed only slightly from each other but have yielded markedly discordant results. For instance, in a recent compilation (2) of normal blood iodine values as given by different workers, a range of 1.1 to 40.0 micrograms per cent is found.

In the present report an attempt has been made to establish the normal blood iodine level for males and females in New York City and to investigate the effects of certain disease conditions on this norm.

\section{METHOD}

After a study of available methods, that of Trevorrow and Fashena $(3,4)$ proved the most satisfactory and reliable and was adopted for use in this clinic. A description of the method as used in this laboratory was recently published by Palmer, Leland and Gutman (5). Duplicate samples of $15 \mathrm{cc}$. of blood were digested in $500 \mathrm{cc}$. digestion flasks which were later connected directly to the distillation apparatus. For this amount of blood, 30 grams of recrystallized potassium dichromate and $90 \mathrm{cc}$. of the chromic acid-sulfuric acid mixture were used.

Small samples were used with bloods suspected of containing large amounts of iodine, as it was shown (5) that quantitative recoveries above 6 micrograms were not always obtained. According to the amount of blood used, the proportions of the reagents were varied as follows:

$\begin{array}{ccc}\text { Blood } & \begin{array}{c}\text { Potassium } \\ \text { dichromate }\end{array} & \text { Acid mixture } \\ \text { cc. } & \text { grams } & c c . \\ 15 & 30 & 90 \\ 10 & 20 & 60 \\ 5 & 10 & 30 \\ 1 & 2 & 10\end{array}$

When 1 cc. or 5 cc. samples were used, digestion was carried out in a $250 \mathrm{cc}$. flask and a transfer was then made to the large distillation flask with the aid of 100 cc. of redistilled water.

During the hour's distillation care was taken to employ a strong current of alkali-washed air, and to collect the same amount of water in the receiving flask as was added to the digestion mixture before distillation (usually $100 \mathrm{cc}$.). New lots of reagents were always tested for traces of iodine before using.

Total iodine recoveries using this method with known solutions of potassium iodide have been reported from this laboratory (5). Using sheep's blood to which known amounts of potassium iodide were added, equally satisfactory recoveries were made.

In each case the usual rigorous precautions were taken against contamination of the blood sample both when it was secured and after it had reached the laboratory.

Results were discarded when the discrepancy between the duplicate specimens exceeded 10 per cent. The average value of the duplicate determinations is given throughout the present report.

\section{Normal blood iodine}

To establish the normal range of blood iodine values, determinations were made on 20 males and 20 females, mostly medical students or laboratory technicians, who were in good health. All were receiving a regular diet, and the blood samples were usually obtained after breakfast. In each case care was taken to ensure that there had been no recent intake of sea food, that tincture of iodine had not been applied to the skin and that iodized salt was not used.

The results are given in Table I and are expressed graphically in Figure 1. The range of the blood iodine for the 20 normal males was 3.8 to 8.6 micrograms, and for the 20 normal females was 3.5 to 10.4 micrograms. The average value for the males was 5.9 micrograms; for the females, 6.8 micrograms; and for the entire group, 6.3 micrograms. 


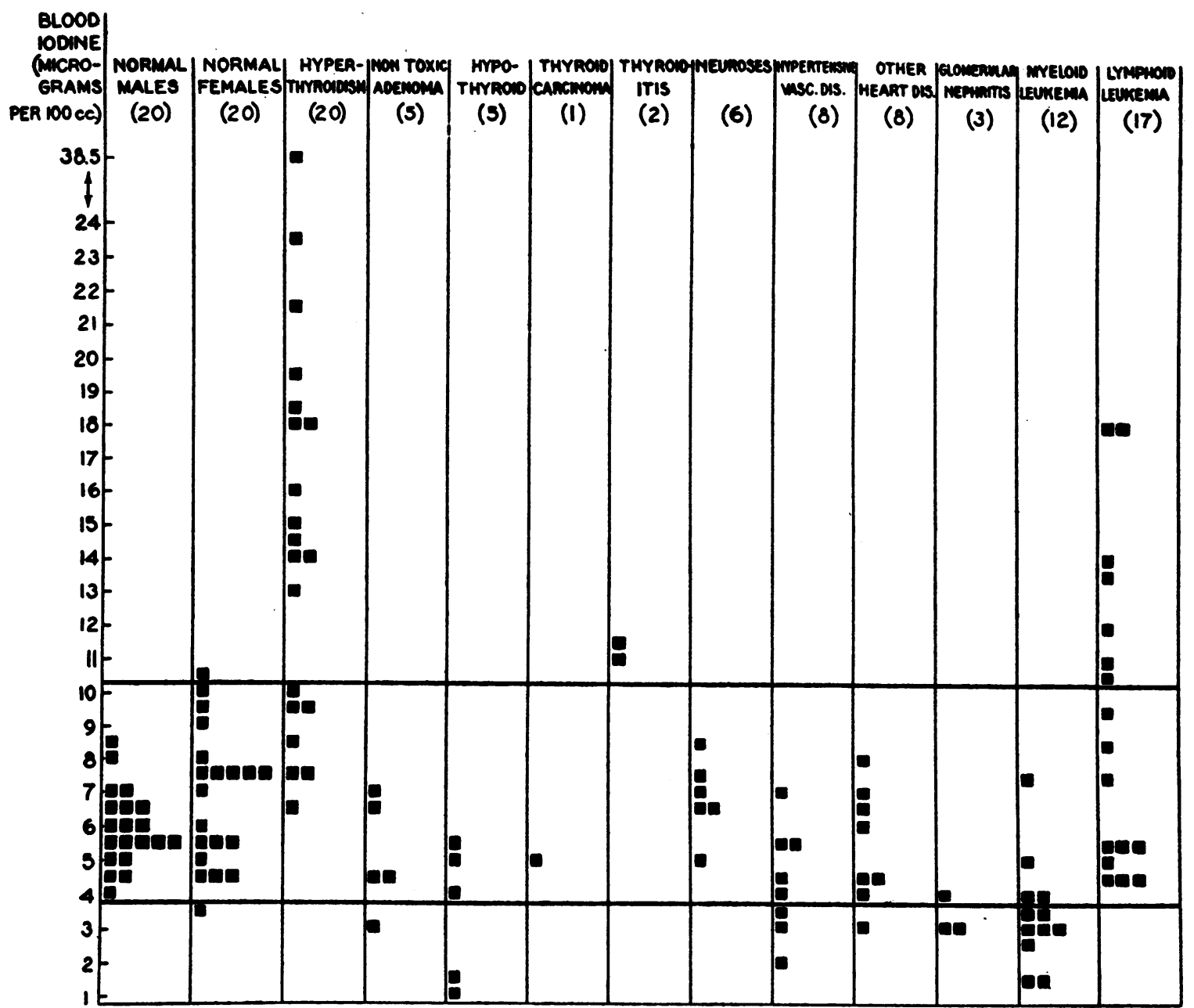

Fig. 1. A Comparison of the Iodine levels in the Blood in Health and in the Various Diseases

discussed in the text and listed at the top of the columns in the figure. The number of cases in each group is indicated in parenthesis below the diagnosis. Each square represents a patient. The approximate normal range is shown by the heavy horizontal lines. A few minor discrepancies will be noted when the figure is compared with the text due to the necessity of charting according to the nearest half microgram instead of in tenths of a microgram as in the tables.

In general, the results herewith reported for normal adults agree closely with the values given recently for normal infants and children in New York City by Fashena (6), using the same method. She found an average blood iodine of 6.6 micrograms in a group of older children.

It will be noted that the blood iodine varies more widely in normal females than in males and that the average for the females is about a microgram higher. In previously reported series, no constant sex difference in the blood iodine level has been found, although it is more often stated that the level is higher in males, contrary to the results here reported. In all events, the difference, if present, is slight and probably of little significance.

A factor of possible importance that could explain higher values in the female is the generally accepted belief that the blood iodine rises significantly on the first days of the menstrual flow. This was first stated by Veil and Sturm (7), and subsequently without dissent by numerous others. In this series the precaution was taken of securing the blood sample during the intermenstrual period.

With two exceptions all determinations were 
TABLE I

Blood iodine of normal adults in New York City

\begin{tabular}{|c|c|c|c|c|c|}
\hline \multicolumn{3}{|c|}{20 Males } & \multicolumn{3}{|c|}{20 Females } \\
\hline Case & Age & $\begin{array}{c}\text { Blood } \\
\text { iodine }\end{array}$ & Case & Age & $\begin{array}{c}\text { Blood } \\
\text { iodine }\end{array}$ \\
\hline $\begin{array}{r}139 \\
123 \\
117 \\
34 \\
92 \\
137 \\
91 \\
3 \\
98 \\
18 \\
31 \\
140 \\
107 \\
43 \\
76 \\
63 \\
27 \\
125 \\
110 \\
82\end{array}$ & $\begin{array}{l}25 \\
27 \\
23 \\
44 \\
37 \\
25 \\
28 \\
26 \\
26 \\
29 \\
26 \\
24 \\
28 \\
34 \\
27 \\
28 \\
25 \\
26 \\
23 \\
28\end{array}$ & $\begin{array}{c}\text { micrograms } \\
\text { per } 100 \text { cc. } \\
8.6 \\
7.9 \\
7.0 \\
6.8 \\
6.5 \\
6.5 \\
6.5 \\
5.9 \\
5.9 \\
5.8 \\
5.6 \\
5.5 \\
5.5 \\
5.3 \\
5.3 \\
5.2 \\
5.1 \\
4.5 \\
4.3 \\
3.8\end{array}$ & $\begin{array}{r}120 \\
19 \\
141 \\
144 \\
136 \\
106 \\
118 \\
138 \\
17 \\
130 \\
143 \\
119 \\
111 \\
121 \\
142 \\
132 \\
112 \\
131 \\
105 \\
124\end{array}$ & $\begin{array}{l}25 \\
25 \\
23 \\
20 \\
30 \\
22 \\
20 \\
36 \\
29 \\
27 \\
19 \\
25 \\
21 \\
22 \\
25 \\
27 \\
28 \\
26 \\
26 \\
21\end{array}$ & $\begin{array}{c}\text { micrograms } \\
\text { per } 100 \text { cc. } \\
10.4 \\
10.2 \\
9.5 \\
9.2 \\
8.1 \\
7.7 \\
7.5 \\
7.4 \\
7.3 \\
7.3 \\
7.0 \\
5.8 \\
5.7 \\
5.6 \\
5.5 \\
5.1 \\
4.6 \\
4.5 \\
4.4 \\
3.5\end{array}$ \\
\hline \multicolumn{2}{|c|}{ Average } & 5.9 & \multicolumn{2}{|c|}{ Average } & 6.8 \\
\hline
\end{tabular}

made in the months of September to January, inclusive. Within this period no seasonal trend was demonstrable. The average blood iodine values by months follow:

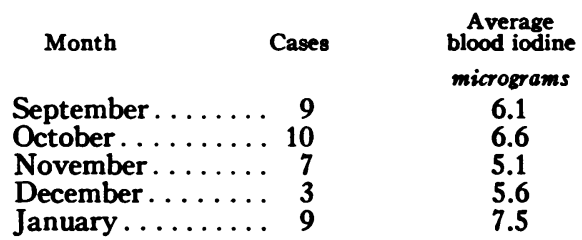

In previous reports, which are too numerous for detailed review here, opinion is divided as to the presence of a seasonal effect on the level of the iodine in the blood. When such an effect has been claimed, a rise in the late summer has been noted, with the low point occurring in the late winter. We have made 5 determinations of the blood iodine in one normal individual and 9 in a second subject. The results are shown in Figure 2. From this it is apparent that, while there was a considerable variation in the blood iodine level of the individual, no seasonal trend was demonstrated.

As a result of this survey of the blood iodine of normal subjects, it was arbitrarily decided to

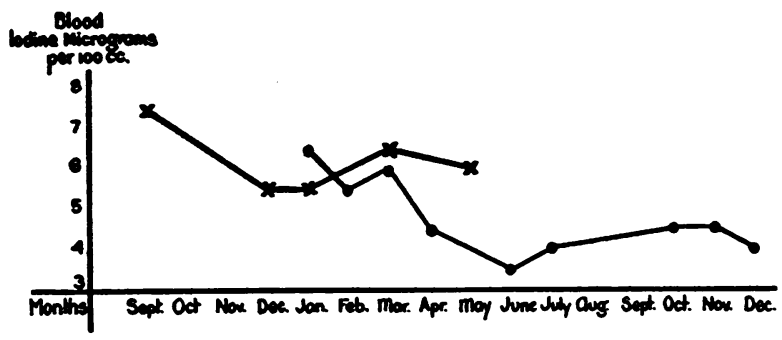

Fig. 2. Relatively Wide Fluctuations Are Shown in the Blood Iodine Level of 2 Individuals But No Seasonal Trend Is Evident

consider the normal range of blood iodine for this method in New York City to be 4.0 to 10.0 micrograms per $100 \mathrm{cc}$. This decision was accompanied by the mental reservation that perhaps the latter figure was too high and that 9.0 micrograms might be a more accurate upper limit of normal.

\section{Thyroid disease}

The intimate relationship of the thyroid to iodine metabolism early attracted the interest of those investigating the iodine content of the blood. As a result, the literature pertaining to the blood iodine in thyroid disease has already become voluminous. A good review has recently appeared (2).

Despite the many previous reports it was considered advisable to study another series of patients with thyroid disorders, particularly with the view of using the results obtained as a basis for comparison with other disease groups.

Hyperthyroidism. There were 20 cases of undoubted hyperthyroidism (Table II and Figure 1). In 17 the changes in the thyroid were diffuse, and in 3 there was a toxic adenoma. As is usually the case, females predominated in this series in the ratio $3: 1$. In no instance had iodine therapy been started.

In 14 patients (70 per cent) the blood iodine was above 10.0 micrograms, the upper limit of normal. In 2 cases ( 10 per cent) the blood iodine was 9.5 micrograms, which may be classed as " high normal." In the remaining 4 patients (20 per cent) the iodine level was entirely normal. These findings correspond rather closely with previously reported series.

The occurrence of hyperthyroidism with a normal blood iodine level has been repeatedly stressed. 
TABLE II

Blood iodine in hyperthyroidism

\begin{tabular}{|c|c|c|c|c|c|c|c|c|}
\hline Case & Sex & Age & Type & Duration & $\begin{array}{l}\text { Basal } \\
\text { metabolic } \\
\text { rate }\end{array}$ & $\begin{array}{c}\text { Serum } \\
\text { cholesterol }\end{array}$ & Blood iodine & Course and remarks \\
\hline $\begin{array}{r}122 \\
25 \\
20 \\
\\
93 \\
39 \\
38 \\
67 \\
77 \\
33 \\
55 \\
48 \\
174 \\
45 \\
28 \\
14 \\
\\
60 \\
85 \\
61 \\
188 \\
159\end{array}$ & $\begin{array}{l}\mathbf{M} \\
\mathbf{F} \\
\mathbf{M} \\
\mathbf{F} \\
\mathbf{F} \\
\mathbf{F} \\
\mathbf{F} \\
\mathbf{F} \\
\mathbf{F} \\
\mathbf{M} \\
\mathbf{M} \\
\mathbf{M} \\
\mathbf{F} \\
\mathbf{F} \\
\mathbf{F}\end{array}$ & $\begin{array}{l}40 \\
56 \\
25 \\
30 \\
60 \\
34 \\
60 \\
33 \\
39 \\
25 \\
54 \\
57 \\
49 \\
48 \\
23 \\
20 \\
41 \\
24 \\
30 \\
34\end{array}$ & $\begin{array}{l}\text { Diffuse } \\
\text { Diffuse } \\
\text { Diffuse } \\
\text { Diffuse } \\
\text { Adenoma } \\
\text { Diffuse } \\
\text { Diffuse } \\
\text { Adenoma } \\
\text { Diffuse } \\
\text { Diffuse } \\
\text { Diffuse } \\
\text { Diffuse } \\
\text { Adenoma } \\
\text { Diffuse } \\
\text { Diffuse } \\
\\
\text { Diffuse } \\
\text { Diffuse } \\
\text { Diffuse } \\
\text { Diffuse } \\
\text { Diffuse }\end{array}$ & $\begin{array}{l}4 \text { months } \\
2 \text { years } \\
1 \text { year } \\
1 \text { year } \\
3 \text { years } \\
1 \text { year } \\
3 \text { years } \\
6 \text { months } \\
14 \text { months } \\
1 \text { year } \\
6 \text { months } \\
1 \text { year? } \\
\text { ? } \\
1 \text { year } \\
2 \text { years } \\
9 \text { months } \\
4 \text { months } \\
4 \text { months } \\
8 \text { months } \\
9 \text { years }\end{array}$ & $\begin{array}{c}\text { per cent } \\
+48 \\
+40 \\
+29 \\
+37 \\
+57 \\
+38 \\
+49 \\
+23 \\
+35 \\
+41 \\
+61 \\
+47 \\
+55 \\
+37 \\
+75 \\
+73 \\
+48 \\
+35 \\
+38 \\
+33 \\
+18\end{array}$ & $\begin{array}{c}\text { mgm. per } \\
100 \text { cc. } \\
200 \\
118 \\
142 \\
147 \\
127 \\
98 \\
156 \\
190 \\
170 \\
175 \\
129 \\
118 \\
159 \\
139 \\
261 \\
125 \\
174 \\
165 \\
208 \\
145 \\
135\end{array}$ & $\begin{array}{c}\text { micrograms } \\
\text { per } 100 \mathrm{cc} \text {. } \\
38.5 \\
23.7 \\
21.4 \\
13.4 \\
19.5 \\
18.3 \\
18.0 \\
17.8 \\
16.0 \\
14.9 \\
14.7 \\
14.2 \\
14.1 \\
12.8 \\
10.2 \\
9.5 \\
9.5 \\
8.3 \\
7.7 \\
7.6 \\
6.7\end{array}$ & $\begin{array}{l}\text { Well } 4 \text { months post-operative. } \\
\text { Well } 1 \text { year post-operative. } \\
\text { Recurrence in } 8 \text { months. } \\
\text { Well } 3 \text { months after second operat ion. } \\
\text { Well } 1 \text { year post-operative. } \\
\text { Well } 3 \text { months post-operative. } \\
\text { Well } 1 \text { year post-operative. } \\
\text { Well } 22 \text { months post-operative. } \\
\text { Well } 18 \text { months post-operative. } \\
\text { Well } 15 \text { months post-operative. } \\
\text { Well } 2 \text { years post-operative. } \\
\text { Improved } 14 \text { months post-operative. } \\
\text { Well after } 5 \text { months radiother apy. } \\
\text { Died. } \\
\text { Well } 1 \text { year post-operative. } \\
\text { Operated for } 3 \text { rd recurrence. Well } 1 \\
\text { year later. } \\
\text { Well } 13 \text { months post-operative. } \\
\text { Well } 3 \text { months post-operative. } \\
\text { No follow-up. } \\
\text { Well } 4 \text { months post-operative. } \\
\text { Operated for } 5 \text { th recurrence. }\end{array}$ \\
\hline
\end{tabular}

The present series is too small to warrant detailed comparison between those patients with an elevated blood iodine and those whose blood iodine was normal. Broadly speaking there do not seem to be significant differences between the two groups with two possible exceptions: (1) none of the five males in the series had a normal iodine level; and (2) of the 3 patients observed at the time of a recurrence of hyperthyroidism, 2 had normal blood iodine values. In the third patient, whose blood iodine was 21.4 micrograms when first observed, the level during a recurrence 3 months later was 13.4 micrograms.

No correlation was evident in the entire series between the level of the blood iodine and the basal metabolic rate or the serum cholesterol values determined by the method of Bloor, Pelkan and Allen (8).

Non-toxic adenoma. In 4 of 5 cases of nontoxic adenoma of the thyroid, normal blood iodine levels were found (Table III and Figure 1). In the fifth case the value was low. This patient also had hypertensive vascular disease (see below). Again, as in the hyperthyroid group, there was no correlation of the blood iodine with the basal metabolic rate or serum cholesterol level.

Hypothyroidism. There were 5 cases in whom the diagnosis of hypothyroidism was established with reasonable certainty. Only 1 presented the clinical syndrome of myxedema. The blood iodine was normal in 2 cases and low in 3 cases (Table III and Figure 1). There was no definite correlation of the blood iodine with the basal metabolic rate or serum cholesterol level.

Thyroiditis. The blood iodine was elevated in 2 cases and the serum cholesterol was low in both, although the basal metabolic rate was low in one and high in the other (Table III and Figure 1). One case was proved by biopsy; in the other the evidence, though presumptive, was strongly suggestive.

Carcinoma of thyroid. In 1 proved case the blood iodine was normal, the basal metabolic rate was elevated, and the serum cholesterol was low (Table III and Figure 1).

"Nervousness." In 6 patients the question of hyperthyroidism had been raised, but after careful study the eventual diagnosis was considered to be some form of nervous imbalance. These individuals were all females and all had normal iodine levels in the blood (Table III and Figure 1). In these cases the basal metabolic rate was normal but the serum cholesterol varied from $140 \mathrm{mgm}$. to $298 \mathrm{mgm}$. per $100 \mathrm{cc}$. 
TABLE III

Blood iodine in miscellaneous thyroid conditions

\begin{tabular}{|c|c|c|c|c|c|c|c|}
\hline Case & Sex & Age & Diagnosis & $\begin{array}{c}\text { Basal } \\
\text { metabolic } \\
\text { rate }\end{array}$ & $\begin{array}{c}\text { Serum } \\
\text { cholesterol }\end{array}$ & Blood iodine & Remarks \\
\hline $\begin{array}{r}97 \\
213 \\
247 \\
207 \\
161 \\
64 \\
62 \\
169 \\
21\end{array}$ & $\begin{array}{l}F \\
F \\
F \\
F \\
F \\
F \\
F \\
M\end{array}$ & $\begin{array}{l}38 \\
47 \\
53 \\
78 \\
52 \\
65 \\
55 \\
60 \\
52\end{array}$ & $\begin{array}{l}\text { Non-toxic adenoma } \\
\text { Non-toxic adenoma } \\
\text { Non-toxic adenoma } \\
\text { Non-toxic adenoma } \\
\text { Non-toxic adenoma } \\
\text { Myxedema } \\
\text { Hypothyroid } \\
\text { Hypothyroid } \\
\text { Hypothyroid }\end{array}$ & $\begin{array}{l}\text { per cent } \\
-1 \\
+8 \\
-5 \\
+22 \\
+10 \\
-25 \\
-25 \\
-9 \\
-17\end{array}$ & $\begin{array}{c}\text { mgm. per } \\
100 \text { cc. } \\
272 \\
186 \\
244 \\
156 \\
221 \\
355 \\
278 \\
345 \\
226\end{array}$ & $\begin{array}{c}\text { micrograms } \\
\text { per } 100 \mathrm{cc} . \\
7.1 \\
6.6 \\
4.7 \\
4.3 \\
2.8 \\
5.8 \\
5.1 \\
3.8 \\
1.7\end{array}$ & $\begin{array}{l}\text { Also rheumatic heart disease. } \\
\text { Also rheumatic heart disease. } \\
\text { Substernal. } \\
\text { Also hypertensive disease. } \\
\text { Also hypertensive disease. } \\
\text { Coronary thrombosis. } \\
\text { Recovering from hyperthyroidism }\end{array}$ \\
\hline $\begin{array}{r}57 \\
101 \\
10 \\
255 \\
65\end{array}$ & $\begin{array}{l}\mathrm{F} \\
\mathrm{F} \\
\mathrm{F} \\
\mathrm{F}\end{array}$ & $\begin{array}{l}61 \\
39 \\
55 \\
47 \\
34\end{array}$ & $\begin{array}{l}\text { Hypothyroid } \\
\text { Carcinoma of thyroid } \\
\text { Thyroiditis } \\
\text { Thyroiditis } \\
\text { "Nervous" ?hyper- } \\
\text { thyroid }\end{array}$ & $\begin{array}{l}-31 \\
+35 \\
-16 \\
+39 \\
+15\end{array}$ & $\begin{array}{l}420 \\
147 \\
124 \\
141 \\
140\end{array}$ & $\begin{array}{r}0.9 \\
5.0 \\
11.3 \\
11.2 \\
8.5\end{array}$ & $\begin{array}{l}\text { Complete thyroidectomy. } \\
\text { Febrile. Biopsy diagnosis. } \\
\text { Biopsy diagnosis. }\end{array}$ \\
\hline 23 & F & 35 & $\begin{array}{l}\text { "Nervous" ?hyper- } \\
\text { thyroid }\end{array}$ & +9 & 224 & 7.4 & \\
\hline 197 & F & 27 & $\begin{array}{l}\text { "Nervous" ?hyper- } \\
\text { thyroid }\end{array}$ & +10 & 241 & 6.9 & \\
\hline 162 & F & 61 & $\begin{array}{l}\text { "Nervous" ?hyper- } \\
\text { thyroid }\end{array}$ & +16 & & 6.7 & \\
\hline 84 & F & 35 & $\begin{array}{l}\text { "Nervous" ?hyper- } \\
\text { thyroid }\end{array}$ & +5 & 298 & 6.6 & \\
\hline 186 & $\mathbf{F}$ & 53 & $\begin{array}{l}\text { "Nervous" ?hyper- } \\
\text { thyroid }\end{array}$ & +2 & 231 & 5.2 & \\
\hline
\end{tabular}

\section{Cardiorenal disease}

Hypertensive vascular disease. All clinicians are familiar with the difficulty sometimes experienced in distinguishing between cases of hyperthyroidism and hypertensive vascular disease. In many instances there is a superficial similarity between the two conditions, but occasionally, particularly when the basal metabolic rate is elevated, the differential diagnosis becomes very difficult indeed. It seemed possible that a determination of the blood iodine in conjunction with the serum cholesterol and basal metabolic rate might be of aid in differentiating between them.

No satisfactory information on the blood iodine level in hypertensive vascular disease is available. A number of reports in the German literature indicate a hyperiodemia in this condition $(7,9$ to 12$)$, while one investigator (13) reported that a normal level was the rule. When an elevated blood iodine was found, the increase did not parallel the rise in basal metabolic rate (11). In the presence of congestive heart failure from whatever cause, the blood iodine was reported high (7) or normal (14). Digitalis was observed to produce a sharp drop in the iodine level (7). In a few cases of renal failure an elevated blood iodine was found $(13,15)$.

TABLE IV

Blood iodine in hypertensive disease

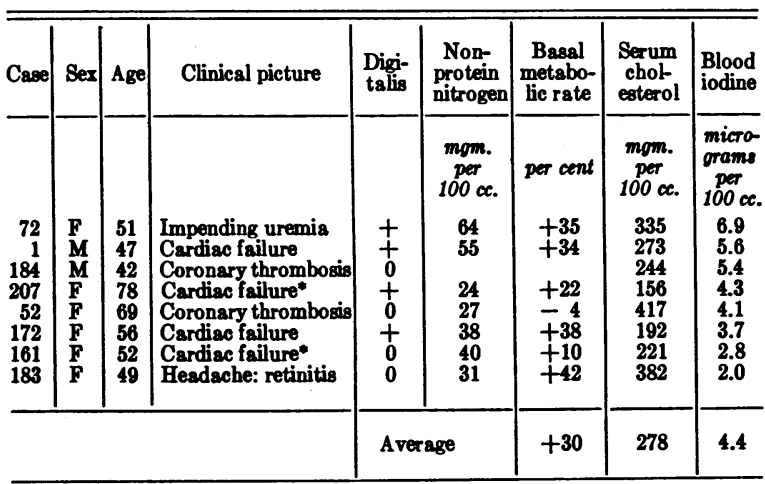

- Also had non-toxic adenoma of thyroid.

The blood iodine was determined in 8 patients with hypertensive vascular disease (Table IV and Figure 1). The only basis for selection was the diagnostic difficulty afforded by all. In each, hyperthyroidism had been considered a possibility. 
The clinical picture varied. Thus, in 4 patients there was congestive heart failure; in 2 instances there had been a coronary thrombosis; and there was 1 case each of impending uremia and severe headache with retinal changes.

The basal metabolic rate was distinctly elevated in $\mathbf{5}$ of the 7 patients on whom the test was made. This, of course, is not characteristic of all series of cases of hypertensive vascular disease, and it should again be emphasized that the patients in this particular group all suggested in some way the diagnosis of hyperthyroidism.

The serum cholesterol was high in half the cases.

The blood iodine values are of interest. In 5 patients the iodine level in the blood fell within the lower half of the normal range. In 3 cases there was a hypoiodemia. There was no correlation between the blood iodine level and the clinical picture presented by the patient, the basal metabolic rate, or the serum cholesterol. Digitalis had been given to 4 patients but, so far as could be inferred, it had had no particular effect in lowering the blood iodine. The 2 patients in this group with the highest blood iodine values had received digitalis; the 2 patients with the lowest levels had not been given the drug. None of the cases had received quinidine or potassium iodide. In one instance (Number 52) some bromide had been given.

It should be noted that the average patient in this group with hypertensive vascular disease had a basal metabolic rate of +30 per cent, a serum cholesterol slightly above normal at $278 \mathrm{mgm}$., and a blood iodine of 4.4 micrograms which is at the lower limit of normal.

Other heart disease. For comparison, a group of 8 patients with rheumatic, syphilitic, or arteriosclerotic heart disease was studied (Table $\mathrm{V}$ and Figure 1). Six of the patients had congestive heart failure and 2 had aneurysms. Digitalis had been given to 5 cases.

The basal metabolic rate had been determined in only 4 of the group. It was normal in each instance, and the average of the 4 determinations was +1 per cent.

In contrast to the hypertensive group, the serum cholesterol was above normal in only 1 case. The average serum cholesterol was $200 \mathrm{mgm}$. as com-
TABLE $\mathbf{V}$

Blood iodine in miscellaneous cases of heart disease

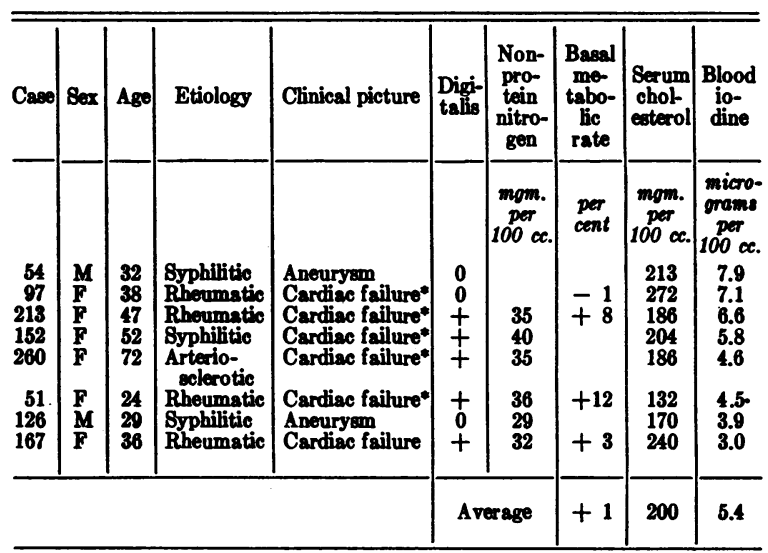

* Also had non-toxic thyroid adenoma.

pared to $278 \mathrm{mgm}$. in the patients with hypertension.

In 6 cases the blood iodine was normal. In 1 patient it was lowered slightly, and in the remaining case there was a definitely low blood iodine. The average for the group was 5.4 micrograms compared with 4.4 micrograms in the hypertensive cases.

TABLE VI

Blood iodine in glomerular nephritis

\begin{tabular}{|c|c|c|c|c|c|c|c|}
\hline Case & Sex & Age & $\begin{array}{c}\text { Non- } \\
\text { pro- } \\
\text { tein } \\
\text { nitro- } \\
\text { gen }\end{array}$ & $\begin{array}{l}\text { Basal } \\
\text { me- } \\
\text { tabo- } \\
\text { lic } \\
\text { rate }\end{array}$ & $\begin{array}{l}\text { Serum } \\
\text { chol- } \\
\text { esterol }\end{array}$ & $\begin{array}{c}\text { Blood } \\
\text { iodine }\end{array}$ & Remarks \\
\hline & & & $\begin{array}{c}\text { mgm. } \\
\text { per } \\
100 \text { cc. }\end{array}$ & $\begin{array}{l}\text { per } \\
\text { cent }\end{array}$ & $\begin{array}{c}\underset{\text { per }}{\operatorname{mgm}} \\
100 \mathrm{cc} .\end{array}$ & $\begin{array}{c}\text { micro- } \\
\text { grams } \\
\text { per } \\
100 \text { cc. }\end{array}$ & \\
\hline 171 & F & 27 & 22 & -13 & 189 & 3.8 & $\begin{array}{l}\text { Also acute rheu- } \\
\text { matic fever }\end{array}$ \\
\hline $\begin{array}{l}104 \\
204\end{array}$ & $\underset{\mathbf{F}}{\mathbf{M}}$ & $\begin{array}{l}14 \\
50\end{array}$ & $\begin{array}{l}35 \\
49\end{array}$ & $\begin{array}{l}-14 \\
-22\end{array}$ & $\begin{array}{l}446 \\
890\end{array}$ & $\begin{array}{l}3.0 \\
2.8\end{array}$ & $\begin{array}{l}\text { Acute nephritis } \\
\text { Nephrotic stage }\end{array}$ \\
\hline
\end{tabular}

Nephritis. Blood iodine determinations were made on 3 patients with glomerular nephritis ( $\mathrm{Ta}$ ble VI and Figure 1). While this series is too small to permit sweeping conclusions, it is of interest to point out that: (1) the basal metabolic rate was low in all; (2) the serum cholesterol was markedly elevated in 2 and normal in the patient with active rheumatic fever; and (3) the blood iodine was uniformly low. These findings are, of course, the same as those seen in hypothyroidism.

Discussion. Although the cases here reported are few and further work is necessary, it seems 
probable that the finding of a low or low normal blood iodine associated with normal or elevated serum cholesterol may be of clinical value in ruling out a thyroid component in patients with hypertension and an elevated basal metabolic rate. This is particularly evident when those cases with recent congestive heart failure in the hyperthyroid (Cases 25, 39, 67) and hypertensive (Cases 1, 161, $172,207)$ groups are compared:

\begin{tabular}{l|c|c|c}
\hline \hline & $\begin{array}{c}\text { Basal } \\
\text { metabolic } \\
\text { rate }\end{array}$ & Cholesterol & $I_{2}$ \\
\hline per cent & mgm. & micrograms \\
Hyperthyroid.... & +34 & 135 & 19.9 \\
Hypertensive... & +26 & 211 & 4.1 \\
\hline
\end{tabular}

In heart disease other than hypertensive, the blood iodine also tends to be low, but this tendency is not as marked as in hypertensive vascular disease and the basal metabolic rate and serum cholesterol are normal.

\section{Leukemia}

In a preliminary report (16) it was pointed out that, in a group of 17 patients with leukemia, it was usually possible to differentiate between the myeloid and lymphoid types on the basis of the blood iodine values. The myeloid group tended to show a low level of iodine in the blood, while in the cases of lymphatic leukemia the blood iodine was either normal or considerably elevated. An additional 12 cases have been studied, and the results confirm the original conclusion. The total group of 29 patients included 12 with myeloid and 17 with lymphoid leukemia.

The results obtained on study of the myeloid cases are shown in Table VII. The blood iodine ranged from 1.3 to 7.4 micrograms, was below normal in 9 cases ( 75 per cent) and the average for the group was only 3.4 micrograms. In 3 patients the iodine values were within normal limits. In one of these (Case 149) it was 4.1 micrograms, which is at the lowest limit of normal. The highest value obtained was 7.4 micrograms in Case 16 . This patient had myeloid leukemia beyond reasonable doubt, but because he left the hospital shortly after the test was performed the determination could not be repeated. Case 133, who also had a normal blood iodine level, was studied at the time of a complete spontaneous remission of the leukemic process when no evidence whatever of leukemia could be found, although her local physician reported that he had found a leukemia blood picture several months previous to hospital admission. Six months after discharge an abnormal blood count was again discovered and the diagnosis of myeloid leukemia was confirmed.

The spleen was enlarged in all patients except the one last discussed. All the cases were anemic and had elevated white blood counts with abnormal leukocytes in the stained smear, again with the ex-

TABLE VII

Blood iodine in myeloid leukemia

\begin{tabular}{|c|c|c|c|c|c|c|c|c|c|c|c|}
\hline Case & Sex & Age & $\begin{array}{c}\text { Duration } \\
\text { of } \\
\text { symptoms }\end{array}$ & $\begin{array}{c}\text { Duration } \\
\text { of } \\
\text { therapy }\end{array}$ & $\begin{array}{c}\text { Red } \\
\text { blood } \\
\text { cells }\end{array}$ & $\begin{array}{l}\text { White } \\
\text { blood } \\
\text { cells }\end{array}$ & $\begin{array}{c}\text { Imma- } \\
\text { ture } \\
\text { white } \\
\text { blood } \\
\text { cells }\end{array}$ & $\begin{array}{l}\text { Basal } \\
\text { metabo- } \\
\text { lic rate }\end{array}$ & $\begin{array}{l}\text { Serum } \\
\text { chol- } \\
\text { esterol }\end{array}$ & $\begin{array}{c}\text { Blood } \\
\text { iodine }\end{array}$ & Interval before death \\
\hline \multirow[t]{2}{*}{$\begin{array}{r}16 \\
133 \\
149 \\
75 \\
41 \\
241 \\
190 \\
164 \\
215 \\
58 \\
13 \\
73\end{array}$} & $\begin{array}{l}\mathbf{M} \\
\mathbf{F} \\
\mathbf{M} \\
\mathbf{M} \\
\mathbf{M} \\
\mathbf{M} \\
\mathbf{F} \\
\mathbf{M} \\
\mathbf{F} \\
\mathbf{F} \\
\mathbf{F} \\
\mathbf{M}\end{array}$ & $\begin{array}{l}27 \\
54 \\
57 \\
30 \\
32 \\
59 \\
51 \\
55 \\
56 \\
56 \\
52 \\
42\end{array}$ & $\begin{array}{c}3 \text { years } \\
\text { ? } \\
5 \text { weeks } \\
6 \text { months } \\
6 \text { months } \\
8 \text { months } \\
1 \text { year } \\
1 \text { months } \\
2 \text { months } \\
10 \text { weeks } \\
4 \text { years } \\
5 \text { years }\end{array}$ & $\begin{array}{c}3 \text { years } \\
? \\
0 \\
0 \\
0 \\
? \\
0 \\
0 \\
0 \\
6 \text { weeks } \\
2 \text { years } \\
3 \text { years }\end{array}$ & $\begin{array}{c}\text { millions } \\
2.9 \\
5.4 \\
2.1 \\
3.5 \\
4.1 \\
4.5 \\
1.8 \\
2.5 \\
2.9 \\
4.4 \\
3.1 \\
3.3\end{array}$ & \begin{tabular}{|r|} 
thousands \\
\\
13.0 \\
5.3 \\
23.6 \\
155.0 \\
104.0 \\
85.0 \\
90.5 \\
26.5 \\
169.0 \\
28.0 \\
47.5 \\
114.0
\end{tabular} & $\begin{array}{c}\text { per cent } \\
9 \\
0 \\
9 \\
31 \\
17 \\
32 \\
47 \\
73 \\
38 \\
9 \\
17 \\
9\end{array}$ & $\begin{array}{r}+33 \\
+30 \\
+31\end{array}$ & $\begin{array}{l}\text { mgm. } \\
\text { per } \\
100 \text { cc. } \\
110 \\
\\
62 \\
144 \\
177 \\
147 \\
202 \\
158 \\
123 \\
206 \\
156 \\
159\end{array}$ & \begin{tabular}{|c} 
micro- \\
grams per \\
100 cc. \\
7.4 \\
4.8 \\
4.1 \\
3.9 \\
3.4 \\
3.4 \\
3.0 \\
2.8 \\
2.8 \\
2.5 \\
1.7 \\
1.3
\end{tabular} & $\begin{array}{l}5 \text { months. } \\
\text { Living at } 1 \text { year. } \\
5 \text { weeks. } \\
\text { Living at } 14 \text { months. } \\
\text { Not followed. } \\
\text { Living at } 1 \text { month. } \\
6 \text { weeks. } \\
1 \text { week. } \\
\text { Living at } 3 \text { months. } \\
\text { Living at } 4 \text { months. } \\
3 \text { months. } \\
\text { Living at } 20 \text { months. }\end{array}$ \\
\hline & & & & & & \multicolumn{2}{|c|}{ Average } & +33 & 150 & 3.4 & \\
\hline
\end{tabular}


TABLE VIII

Blood iodine in lymphoid leukemia

\begin{tabular}{|c|c|c|c|c|c|c|c|c|c|c|c|}
\hline Case & Sex & Age & $\begin{array}{c}\text { Duration } \\
\text { of } \\
\text { symptoms }\end{array}$ & $\begin{array}{l}\text { Duration } \\
\text { of } \\
\text { therapy }\end{array}$ & $\begin{array}{c}\text { Red } \\
\text { blood } \\
\text { cells }\end{array}$ & $\begin{array}{l}\text { White } \\
\text { blood } \\
\text { cells }\end{array}$ & Lymph- & $\begin{array}{c}\text { Basal } \\
\text { metabo- } \\
\text { lic rate }\end{array}$ & $\begin{array}{l}\text { Serum } \\
\text { chol- } \\
\text { esterol }\end{array}$ & $\begin{array}{l}\text { Blood } \\
\text { iodine }\end{array}$ & Interval before death \\
\hline $\begin{array}{r}7 \\
81 \\
44 \\
15 \\
9 \\
113 \\
88 \\
40 \\
5 \\
148 \\
203 \\
242 \\
175 \\
90 \\
4 \\
56\end{array}$ & $\begin{array}{l}\mathbf{M} \\
\mathbf{M} \\
\mathbf{M} \\
\mathbf{F} \\
\mathbf{M} \\
\mathbf{F} \\
\mathbf{M} \\
\mathbf{M} \\
\mathbf{M} \\
\mathbf{M} \\
\mathbf{F} \\
\mathbf{M} \\
\mathbf{M} \\
\mathbf{F} \\
\mathbf{M} \\
\mathbf{M} \\
\mathbf{M}\end{array}$ & $\begin{array}{l}56 \\
69 \\
64 \\
47 \\
56 \\
25 \\
73 \\
61 \\
56 \\
64 \\
75 \\
19 \\
28 \\
63 \\
75 \\
55 \\
56\end{array}$ & $\begin{array}{l}6 \text { months } \\
6 \text { weeks } \\
2 \text { years } \\
2 \text { years } \\
2 \text { years } \\
11 \text { months } \\
18 \text { months } \\
7 \text { months } \\
6 \text { months } \\
? \\
6 \text { months } \\
4 \text { months } \\
3 \text { months } \\
2 \text { years }+ \\
15 \text { months } \\
2 \frac{1}{3} \text { years } \\
7 \frac{1}{2} \text { years }\end{array}$ & $\begin{array}{c}0 \\
0 \\
? \\
2 \text { years } \\
1 \text { year } \\
0 \\
0 \\
1 \text { month } \\
0 \\
0 \\
6 \text { months } \\
0 \\
2 \text { weeks } \\
6 \text { months } \\
? \\
2 \text { years } \\
6 \text { years }\end{array}$ & $\begin{array}{c}\text { millions } \\
3.9 \\
4.0 \\
5.1 \\
1.4 \\
4.6 \\
3.4 \\
4.6 \\
3.7 \\
4.5 \\
3.4 \\
4.3 \\
6.9 \\
1.9 \\
3.8 \\
4.9 \\
5.0 \\
3.8\end{array}$ & \begin{tabular}{|c|} 
thousands \\
43.0 \\
13.0 \\
59.0 \\
12.0 \\
6.6 \\
56.0 \\
9.0 \\
31.0 \\
45.0 \\
44.9 \\
5.5 \\
88.0 \\
331.0 \\
38.0 \\
9.0 \\
19.0 \\
5.0
\end{tabular} & $\begin{array}{c}\text { per cent } \\
86 \\
33 \\
88 \\
90 \\
68 \\
95 \\
55 \\
79 \\
92 \\
87 \\
18 \\
75 \\
97 \\
93 \\
76 \\
70 \\
43\end{array}$ & $\begin{array}{c}\text { per cent } \\
+45 \\
+30 \\
+31 \\
+67 \\
+42\end{array}$ & $\begin{array}{l}\text { mgm. } \\
\text { per } \\
100 \text { cc. } \\
220 \\
72 \\
340 \\
191 \\
185 \\
262 \\
100 \\
195 \\
216 \\
169 \\
192 \\
312 \\
174 \\
280\end{array}$ & 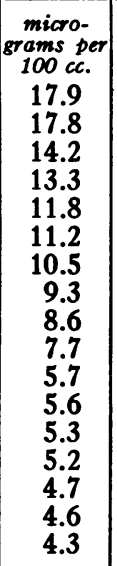 & $\begin{array}{l}3 \text { weeks. } \\
\text { Not followed. } \\
7 \text { months. } \\
6 \text { months. } \\
\text { Living at } 8 \text { months. } \\
\text { Living at } 1 \text { year. } \\
\text { Living at } 18 \text { months. } \\
\text { Living at } 4 \text { months. } \\
\text { Living at } 18 \text { months. } \\
2 \text { weeks. } \\
\text { Living at } 5 \text { months. } \\
4 \text { weeks. } \\
1 \text { month. } \\
6 \text { months. } \\
\text { Living at } 2 \text { years. } \\
\text { Living at } 1 \frac{1}{1} \text { years. } \\
\text { Living at } 1 \frac{1}{2} \text { years. }\end{array}$ \\
\hline & & & & & & Avera & & +40 & 213 & 9.3 & \\
\hline
\end{tabular}

ception of the patient in remission. The basal metabolic rate was distinctly elevated ranging from +30 per cent to +38 per cent in the 5 cases in which it was determined. The serum cholesterol tended to be low. It ranged from $62 \mathrm{mgm}$. to 206 mgm., and the average for the group was 150 mgm.

As may be seen in Table VII, there is no relationship between the blood iodine level and the age or sex of the patient, the duration of symptoms, the amount of radiotherapy, the red blood count, the white blood count, the percentage of immature cells, the basal metabolic rate, the serum cholesterol, or the length of life subsequent to the analysis.

The blood iodine determination was repeated in 3 patients. Case 75 was found to have a blood iodine of 3.3 micrograms 14 months after his original examination had shown a level of 3.9 micrograms. Case 13 rose in $2 \frac{1}{2}$ months from 1.7 to 3.0 micrograms ; and Case 73 was constant at 1.3 and 1.1 micrograms during 5 months.

It should perhaps be noted that Case 164; here included as myeloid leukemia, was classified by the pathologist at autopsy as an example of monocytic leukemia.

The data on the 17 patients with lymphoid leukemia are given in Table VIII. With a few ex- ceptions the blood count was high and the percentage of lymphocytic cells was increased. The majority of the patients were anemic. With two exceptions (Cases 148, 203) there was palpable lymphadenopathy associated in a majority of instances with splenomegaly.

The basal metabolic rate was determined in 10 cases and was elevated in all. It ranged from +19 per cent to +67 per cent, with an average of +40 per cent.

The serum cholesterol varied widely. Although the average value of $213 \mathrm{mgm}$. is normal, individual determinations ranged from $72 \mathrm{mgm}$. to $375 \mathrm{mgm}$. If the normal range is assumed to be approximately from 160 to $250 \mathrm{mgm}$., it will be noted that in 3 cases there was a hypocholesterolemia and in 5 the serum cholesterol was above normal. The latter is of some interest in view of the consistent elevation of the basal metabolism.

The blood iodine also varied over a wide range but, whereas in the myeloid group 75 per cent of the cases had sub-normal levels of iodine in the blood and 25 per cent were normal, in the lymphoid leukemias 59 per cent (10 cases) were normal, 41 per cent ( 7 cases) were above normal, and not a single case had a hypoiodemia. The range of blood iodine values was from 4.3 to 17.9 micrograms, and the average was 9.3 micrograms. 
A study of the data presented in Table VIII shows no other apparent difference between those patients with an elevated blood iodine and those with normal values. Again, as in the myeloid group, there is no relationship between the blood iodine level and the age or sex of the patient, the duration of symptoms or of therapy, the red or white blood cell counts, the percentage of lymphocytic cells, the basal metabolic rate, the serum cholesterol, or the subsequent duration of life.

Repeated determinations were made on 1 patient (Case 4). Two months after the blood iodine was found to be 4.7 micrograms, the test was repeated and the iodine found to be unchanged at 4.6 micrograms. Thirteen months later a third determination showed a rise to 5.6 micrograms with an associated increase in white blood count to 32,000 from 9,000 cells.

An elevated blood iodine was found in 2 cases of lymphosarcoma. One of these subsequently developed a leukemic blood picture. Five additional cases of lymphosarcoma had blood iodine values well within the normal range.

In 6 cases of Hodgkin's disease, the blood iodine was normal in 5 and slightly elevated in 1 (10.6 micrograms).

Ten cases of neoplasm of various sites with widespread metastasis were studied. A surprisingly wide variation in blood iodine levels was found. In a case of carcinoma of the stomach and one of unknown origin the blood iodine was low (2.6 and 3.8 micrograms). Normal values were found in 5 cases in which the primary site was the stomach ( 2 cases), adrenal, cecum, and unknown. In the remaining 3 cases the neoplasm originated in the breast, kidney and stomach, and a hyperiodemia was demonstrated (15.0, 20.0, and 32.2 micrograms).

Discussion. As was stated before (16), the cases of leukemia with blood iodine determinations reported in the literature are not more than half a dozen in number. It has been assumed apparently that the level of blood iodine was generally increased in both types of leukemia. Increased blood iodine values have been reported in myeloid leukemia $(17,19,20)$ and in the lymphoid type $(7,17,19)$. A normal value was found in 1 case of myeloid leukemia (19), and Stevens (21), using a method closely resembling the one employed in this work, reported a normal blood iodine in 1 case of lymphoid leukemia.

The contrast between the iodine range in the blood of the 12 myeloid cases and the 17 in the lymphoid group is well shown in Figure 1, and on comparison of Tables VII and VIII. In only 2 cases was there any overlapping of the two groups. In both these instances, patients with myeloid leukemia had normal blood iodine values. Both have been previously discussed. In 1 no explanation for the discrepancy could be adduced; the other patient was in a spontaneous remission without any evidence of leukemia.

In both groups there was a complete lack of correlation between the blood iodine level and various other clinical features. In both groups there was an increase in the basal metabolic rate. The average was slightly higher in the lymphoid group $(+40$ per cent as compared with +33 per cent). The serum cholesterol in this group was also higher. The average in lymphoid leukemia was $213 \mathrm{mgm}$. while in the myeloid type it was 150 mgm., an abnormally low figure. The striking difference between the two groups, however, was in the figures for the blood iodine. The average for the group of patients with myeloid leukemia was 3.4 micrograms compared with 9.3 micrograms for the lymphoid group.

\section{SUMMARY}

1. The blood iodine of 20 normal males living in New York City ranged from 3.8 to 8.6 micrograms with an average of 5.9 micrograms. Twenty normal females had blood iodine values varying from 3.5 to 10.4 micrograms and averaging 6.8 micrograms. Although a considerable variation occurred in the blood iodine level of 2 individuals, no seasonal trend could be demonstrated.

2. The normal range for the blood iodine was arbitrarily set at 4.0 to 10.0 micrograms.

3. In 20 cases of hyperthyroidism the blood iodine was elevated in 14 (70 per cent), normal in 6 ( 30 per cent). In 4 of 5 cases of non-toxic adenoma, the blood iodine was normal, while in the fifth patient it was low. In 5 cases of hypothyroidism the blood iodine was low normal or low. The iodine level in the blood was elevated in 2 cases of thyroiditis, normal in 1 case of car- 
cinoma of the thyroid, and normal in 6 neurotic females. There was no correlation between the blood iodine level and the serum cholesterol or basal metabolic rate within each of these groups.

4. In hypertensive vascular disease the blood iodine was low or low normal and the serum cholesterol was normal or even high when the basal metabolic rate was increased. It was suggested that these findings would aid in differentiating hypertensive vascular disease from hyperthyroidism. In heart disease other than hypertensive the blood iodine tended to be low, but the serum cholesterol and basal metabolic rate were normal.

5. In 12 cases of myeloid leukemia the blood iodine was abnormally low in 75 per cent, normal in 25 per cent. The range was from 1.3 to 7.4 micrograms, with an average of 3.4 micrograms. Contrasted to this, in a series 17 patients with lymphoid leukemia, the blood iodine was normal in 59 per cent, high in 41 per cent, and low in not a single instance. The range was from 4.3 to 17.9 micrograms and the average was 9.3 micrograms. With the exception of 2 cases -1 in a spontaneous remission-there was no overlapping of the two groups.

The authors are indebted to Dr. Kenneth R. McAlpin for his aid in securing blood samples from the leukemia patients reported in this paper.

\section{BIBLIOGRAPHY}

1. von Fellenberg, T., Untersuchungen über das Vorkommen von Jod in der Natur. I. Biochem. Ztschr., 1923, 139, 371.

2. Elmer, A. W., Iodine metabolism and thyroid function. Oxford University Press, London, 1938.

3. Trevorrow, V., and Fashena, G. J., The determination of iodine in biological material. J. Biol. Chem., 1935, 110, 29.

4. Fashena, G. J., and Trevorrow, V., A note on the determination of iodine in biological material. J. Biol. Chem., 1936, 114, 351.

5. Palmer, W. W., Leland, J. P., and Gutman, A. B., The micro-determination of thyroxine in the thy- roid gland of the new-born. J. Biol. Chem., 1938, $125,615$.

6. Fashena, G. J., A study of the blood iodine in childhood. J. Clin. Invest., 1938, 17, 179.

7. Veil, W. H., and Sturm, A., Beitrage zur Kenntnis des Jodstoff wechsels. Deutsches Arch. f. klin. Med., 1925, 147, 166.

8. Bloor, W. R., Pelkan, K. F., and Allen, D. M., Determination of fatty acids (and cholesterol) in small amounts of blood plasma. J. Biol. Chem., 1922, 52, 191.

9. Moebius, W., Vergleichende Blutjoduntersuchungen bei trockener und feuchter Veraschung. Biochem. Ztschr., 1932, 253, 275.

10. Buerger, M., and Moebius, W., Der Jod-und Cholesteringehalt des Blutes in seinen Beziehungen zur Essentiellen Hypertonie. Klin. Wchnschr., 1934, 13, 1349.

11. Moebius, W., and Nolte, F. A., Verhalten von Grundumsatz und Blutjod bei Thyreotoxikosen. Ztschr. f. klin. Med., 1935, 128, 174.

12. Paal, H., Elektrochemische Blutjodbestimmung. Klin. Wchnschr., 1935, 14, 1394.

13. Lohr, H., Beitrage zur Kenntnis des Jodstoff wechsels. I. Blutjodstudien unter physiologischen Verhältnissen. Arch. f. exp. Path. u. Pharmakol., 1936, 180, 332.

14. Kisch, F., Uber das Verhalten des Blutjodspiegels Kreislaufkranker. Wien. klin. Wchnschr., 1934, 47, 1317.

15. Baldauf, L. K., and Pincussen, L., Untersuchungen über den Jod- und Bromgehalt des Blutes. Klin. Wchnschr., 1930, 9, 1505.

16. Turner, K. B., McAlpin, K. R., and DeLamater, A., Blood iodine in leukemia. Proc. Soc. Exper. Biol. and Med., 1938, 39, 55.

17. Curtis, G. M., Davis, C. B., and Phillips, F. J., Significance of the iodine content of human blood. J. A. M. A., 1933, 101, 901.

18. Curtis, G. M., and Cole, V. V., The blood iodine in thyroid disease. Tr. Am. A. Study Goiter, 1934, p. 142.

19. Curtis, G. M., and Barron, L. E., The urinary loss of iodine following total thyroidectomy. Surgery, 1937, 1, 92.

20. Dassen, R., and del Castillo, E. B., El metabolesimo basal y la yodemia en la leucemia mielógena. Sus modificaciones con la diyodotirosina. Semana méd., 1934, 41, 1854.

21. Stevens, C. D., Determination of iodine in biological materials; simplified technique. J. Lab. and Clin. Med., 1937, 22, 1074. 